\title{
KAJIAN PENERAPAN SISTEM MANAJEMEN MUTU PADA PROYEK KONSTRUKSI
}

\author{
Melchior Bria1, Anastasia H. Muda ${ }^{2}$, Yermias Elvis Lay ${ }^{3}$
}

\begin{abstract}
Abstrak :
Dalam pembangunan infrastruktur, mutu konstruksi kita masih jauh dari harapan. Hal ini disebabkan salah satunya adalah belum membudayanya penerapan sistem manajemen mutu pada proses/tahapan siklus proyek. Untuk itu perlu dikaji kriteria-kriteria yang dapat dipakai untuk menerapkan SMM dan bagaimana penerapan SMM pada Proyek Konstruksi? Untuk itu, dalam penelitian ini metode yang digunakan adalah metode survey dimana responden adalah beberapa perusahan jasa konstruksi yang ada di wilayah Kupang dan sekitarnya, Kefamenanu dan Soe. Hasil identifikasi diuji validitas dan reliabilitas sehingga diperoleh ranking faktor sub kriteria dalam kriteria. Selanjutnya dengan menggunakan teknik zero one akan diperoleh suatu gambaran tentang penerapan system manajemen mutu. Dari hasil analisis diperoleh kriteria dan subkriteria yang valid dan reliable adalah Identifikasi standar mutu; Penentuan cara memenuhi standar mutu; Pelaksanaan Rencana Mutu; Kegiatan sistemik dalam melaksanakan mutu untuk memenuhi persyaratan yang telah ditetapkan; Memantau hasil? hasil spesifik Proyek, Menentukan penyimpangan terhadap standar, Mengidentifikasi tindakan untuk menghilangkan penyebab kinerja yang tidak memuaskan. Sedangkan penerapan dari kriteria di atas sebagai manifestasi penerapan system manajemen mutu dalam industri jasa konstruksi pada ketiga wilayah penelitian adalah belum berjalan sebagaimana mestinya, yang ditunjukan dari jumlah bobot 13,79 lebih tinggi dari penerapan SMM secara sistematis (bobot 12,07).
\end{abstract}

Kata Kunci : Manajamen, Mutu, Konstruksi.

\section{PENDAHULUAN}

"Kegagalan konstruksi umumnya disebabkan oleh salah urus". Demikian kesimpulan singkat dari Pendapat Bank Dunia ketika mengomentari tentang dunia jasa konstruksi Indonesia (2004). Pernyataan singkat tersebut, kalau mau dicermati lebih jauh, sangatlah kompleks. Salah urus tersebut menyebabkan penyimpangan hampir di semua tahapan pelaksanaan proyek, mulai dari tahap perencanaan hingga operasi dan pemeliharaan. Persoalan yang mencolok adalah ketidakindahan atau ketidakcakapan dalam pengelolaan suatu pekerjaan konstruksi. Penguasaan dan pemahaman rekayasa keteknikan belum men- cukupi jika tidak ditunjang dengan suatu model manajemen yang berbasis pada pencapaian sasaran proyek.p

Sinyalemen Bank Dunia tersebut ternyata tidak lantas terjadi perubahan yang signifikan tetapi dunia jasa konstruksi di satu sisi mengalami keterpurukan seiring dengan maraknya berbagai penyimpangan yang berujung pada rendahnya kualitas pekerjaan konstruksi. Hal ini, umumnya terjadi pada proyek-proyek berskala kecil sampai sedang yang umumnya minim pengawasan dan penerapan manajemen yang sistematis.

Sebagai contoh, di lingkup regional wilayah Nusa Tenggara Timur, banyak ditemui kasus 
terjadinya kegagalan konstruksi yang berujung pada masalah hukum. Data yang diperoleh dari Investigasi Tim Teknis PNK, di tahun 2013 saja ada 5 (lima) kasus kegagalan proyek konstruksi yang ditangani pihak berwajib dengan nilai kerugian negara mencapai di atas 5 milyar lebih. Suatu nilai yang cukup besar tentunya.

Di sisi lain, kenyataan menunjukkan bahwa banyak usaha jasa konstruksi yang hanya sekadar "Papan Nama" alias ada nama tetapi tidak ada kantor, peralatan tidak punya, sumber daya manusia terbatas bahkan ada yang tidak ada sama sekali. Data dari Dinas PU NTT (2011), terdapat 200-an perusahaan jasa konstruksi yang setelah di tinjau terbukti tidak memenuhi kualifikasi menjadi sebuah badan usaha, akan tetapi memiliki ijin operasioanl perusahaan. Hal ini jelas menunjukkan suatu fakta bahwa mutu konstruksi kita masih jauh dari harapan.

Pertanyaannya, sebenarnya apa yang sesungguhnya terjadi. Apakah memang kegagalan proyek konstruksi semata-mata keinginan para pelaku konstruksi saja ataukah kelemahan justru pada sistem pengelolaan proyek yang belum memberikan jaminan pada pencapaian kualitas pekerjaan yang sesuai dengan harapan. Atau dengan lain kata, sistem manajemen mutu belum diterapkan secara baik dan benar.

Untuk itu perlu dilakukan kajian terhadap kriteria-kriteria apa saja yang dibutuhkan dalam penerapan sistem manajemen mutu pada proyek konstruksi dan bagaimana penerapan manajemen mutu pada proyek-proyek konstruksi.

\section{TINJAUAN PUSTAKA}

Mutu adalah Gambaran dan Karakteristik menyeluruh dari barang atau jasa yang menunjukkan kemampuannya dalam menuangkan kebutuhan yang ditentukan atau yang tersirat (Moeljanto, 2004)

Menurut Philip Crosby : Mutu adalah kesesuaian terhadap persyaratan (Quality has to be defined a conformance to requirements).

Sedangkan ahli mutu lainnya, Edwards Deming menganggap pihak manajemen sangat penting dan memikul tanggungjawab besar, baik di tingkat individu maupun di tingkat perusahaan, dengan meyakini bahwa manajemen bertanggungjawab atas $94 \%$ masalah mutu. Deming juga mendorong penggunaan pendekatan sistematis untuk pemecahan masalah dan mengusulkan siklus PDCA yang sudah terkenal. Siklus PDCA juga dikenal sebagai siklus Deming.

Agar sebuah organisasi bisa berfungsi secara obyektif, organisasi tersebut harus mengetahui dan mengatur berbagai kegiatan yang saling terkait. Kegiatan menggunakan sumber daya yang diatur dan memungkinkan mengubah input menjadi output bisa dianggap sebagai proses. Penerapan sistem proses dalam sebuah organisasi, digabungkan dengan identifikasi dan interaksi proses-proses tersebut dan pengaturannya bisa disebut pendekatan proses.

Dalam proses, lingkaran Deming (PDCA) memberikan panduan yang jelas. PDCA bukan hanya dilakukan saat awal suatu kegiatan tetapi juga dapat diterapkan saat melakukan perbaikan berkelanjutan.

P Plan : (Perencanaan) proses perbaikan

D Do : (Pelaksanaan) Perbaikan, pengumpulan dan analisis ata

C Check : (Pemeriksaan) Hasil dan Peserta didikan yang diambil.

A Act : (Bertindak) dengan menggunakan, menyesuaikan atau mengabaikan perubahan.

Sedangkan faktor-faktor yang mempengaruhi persepsi orang terhadap mutu antara lain, sesuai dengan kebutuhan pemilik pekerjaan; Harga kontrak; Waktu penyerahan pekerjaan; Kehandalan; Bebas dari kerusakan bisa berumur panjang.

Beberapa penelitian terdahulu :

1.Febriandi Raymond (2007), Sistem Manajemen Mutu ISO 9001:2000 pada Industri Jasa Konstruksi mengemukakan bahwa implementasi sistem manajemen mutu berbasis ISO 9001:2000 dapat meningkatkan Nilai dari Kontraktor dalam memenangkan tender 
Proyek. Dan ternyata penerapan manajemen mutu dapat memberikan keuntungan yang signifikan bagi kontraktor baik dari penghematan biaya dan juga nilai jual kontraktor.

2.Latief, Yusuf (2009), Penerapan Metode Six Sigma dalam penjagaan kualitas pada proyek konstruksi, mengemukakan bahwa umumnya dalam proyek konstruksi sudah diterapkan manajemen mutu. Akan tetapi, tidak ditemukan bahwa penerapan itu merupakan suatu sistem yang baku.

\section{METODE PENELITIAN}

Penelitian ini merupakan penelitian survey yaitu melakukan serangkaian pengukuran terhadap suatu permasalahan dengan mengemukakan beberapa kriteria dan dari kriteria tersebut dapat dipakai untuk menilai suatu fenomena atau gejala.

Untuk itu penelitian ini dikerjakan dalam 3 tahapan utama yaitu identifikasi faktor yang mempengaruhi penerapan mutu, analisis faktor dan kajian penerapan sistem manajemen mutu berdasarkan pada kriteria yang telah diperoleh.

Kriteria/Faktor disusun berdasarkan kajian pustaka dan hasil identifikasi kondisi eksisting. Rumusan kriteria ini kemudian dijadikan bahan penyusun kuesioner penentuan kriteria. Kuesioner didesain sedemikian rupa sehingga pilihan jawaban akan menghasilkan skor berdasarkan tingkat kepentingannya terhadap substansi pertanyaan kuesioner.

Skor yang dipakai dalam kuesioner adalah menggunakan angka dari $1-5$ untuk menyatakan tingkatan pengaruh berdasarkan skala Likert, yaitu : Skor 5 untuk menyatakan tingkatan sangat penting hingga Skor 1 untuk menyatakan tingkatan sangat tidak penting

Responden yang direncanakan dalam penelitian ini adalah Orang yang mengerti benar terhadap masalah yang dibahas, Merasakan akibat dari suatu masalah, Mempunyai kepentingan terhadap masalah tersebut. Responden adalah para Kontraktor yang pernah mengerjakan Proyek Konstruksi baik bidang SDA, Bina Marga maupun bidang Cipta Karya
Hasil dari survey kuesioner penentuan kriteria tersebut selanjutnya diuji menggunakan uji statistik untuk menentukan subkriteria yang akan dipakai dalam penentuan prioritas pemeliharaan jalan. Perhitungan Statistik ini menggunakan Program SPSS for Windows versi 12.0.

Dari hasil identifikasi dan penentuan kriteria/faktor akan diperoleh bobot masingmasing faktor sebagai dasar penentuan ranking faktor. Selanjutnya, faktor-faktor yang dinyatakan valid dan reliabel digunakan untuk menilai apakah faktor-faktor tersebut diterapkan dalam pelaksanaan proyek-proyek konstruksi. Analisis ini menggunakan metode kuantitatif subyektif.

Metode ini merupakan metode yang digunakan untuk menentukan pilihan dengan menggunakan metode penilaian dan pembobotan terhadap beberapa kriteria yang mempengaruhi pengambil keputusan dalam membuat keputusan.

Metode ini didasari pada penilaian terhadap faktor-faktor yang dipertimbangkan dari alternatif yang tersedia. Mengingat bahwa skorskor tersebut adalah penilaian subyektif dari peneliti maka metode ini diberi nama metode kuantitatif subyektif (Suratman, 2001).

Teknik yang digunakan adalah Teknik Zero One dimana dari kriteria dan sub krteria yang telah dianalisis, disusun dalam suatu pembobotan untuk menentukan pilihan apakah Penerapan Sistem Manajemen Mutu dijalankan secara baik atau tidak.

\section{HASIL DAN PEMBAHASAN}

Dalam membangun sistem manajemen mutu, diperlukan beberapa indikator yang dapat dijadikan sebagai rujukan awal menilai penerapan SMM. Dalam penelitian ini, tidak dimaksudkan untuk menilai apakah SMM diterapkan berdasarkan suatu standar tertentu, akan tetapi lebih pada bagaimana perusahaan jasa konstruksi menerapkan prinsip-prinsip mutu dalam perencanaan, pelaksanaan dan pengendalian pekerjaan di lapangan. Secara khusus proses dalam manajemen mutu didefinisikan sebagai berikut : 


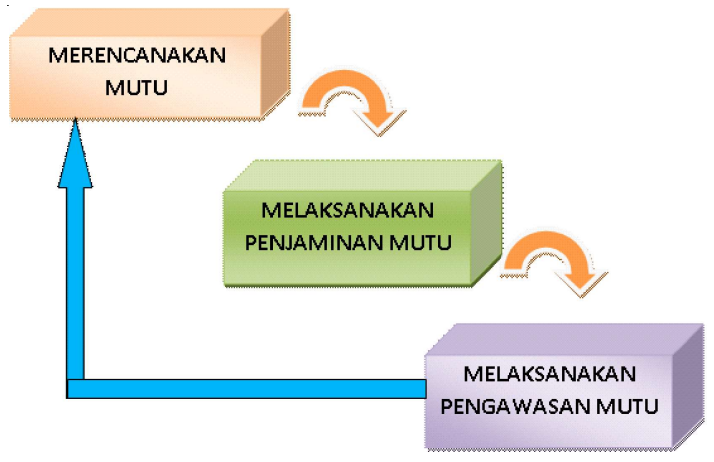

Gambar 1. Proses manajamen mutu

Dari proses manajemen mutu di atas dapat diidentifikasi kriteria-kriteria yang akan digunakan untuk menilai penerapan sistem manajemen mutu pada proyek-proyek konstruksi.

Tabel 1. Identifikasi Kriteria

\begin{tabular}{|c|c|}
\hline PROSES & KRITERIA \\
\hline Perencanaan Mutu & 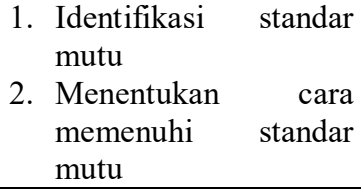 \\
\hline $\begin{array}{l}\text { Pelaksanaan } \\
\text { Penjaminan Mutu }\end{array}$ & 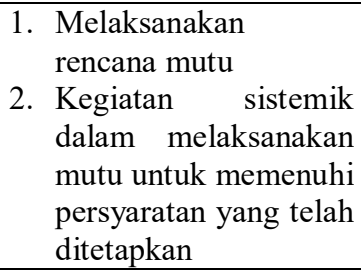 \\
\hline $\begin{array}{l}\text { Pelaksanaan } \\
\text { Pengawasan Mutu }\end{array}$ & $\begin{array}{l}\text { 1. Memantau hasil-hasil } \\
\text { spesifik Proyek } \\
\text { 2. Menentukan } \\
\text { penyimpangan } \\
\text { terhadap standar } \\
\text { 3. Mengidentifikasi } \\
\text { tindakan untuk meng- } \\
\text { hilangkan penyebab } \\
\text { kinerja yang tidak } \\
\text { memuaskan }\end{array}$ \\
\hline
\end{tabular}

Selanjutnya dilakukan kajian terhadap validitas dan reliabilitas dengan hasil bahwa semua variabel atau kriteria pada Tabel 1 adalah valid dan reliabel dimana ditunjukkan dengan nilai Korelasi Product Moment dimana nilai $r$ hitung lebih besar dari r kritis. Sedangkan reliabilitas keseluruhan item diperoleh dengan mengoreksi angka korelasi yang diperoleh dengan memakai rumus Spearmean Brown (Split Half):

$$
\begin{aligned}
& r=\frac{2 r_{b}}{1+r_{b}}=\frac{2 \times 0,940}{1+0,940} \\
& r=0,9690>\text { koefisien korelasi } 0,940
\end{aligned}
$$

Dengan demikian alat ukur kriteria yang dipakai adalah reliabel.

Tabel 2. Analisa korelasi product momen

\begin{tabular}{|l|l|l|l|l|}
\hline No & Kriteria & $\begin{array}{c}\text { r } \\
\text { hitung }\end{array}$ & $\begin{array}{c}\text { r } \\
\text { kritis }\end{array}$ & Ket. \\
\hline $\mathbf{1}$ & $\mathbf{2}$ & $\mathbf{3}$ & $\mathbf{4}$ & $\mathbf{5}$ \\
\hline A1 & $\begin{array}{l}\text { Identifikasi } \\
\text { Standar } \\
\text { Mutu }\end{array}$ & 0.913 & 0.482 & Valid \\
\hline A2 & $\begin{array}{l}\text { Penentuan } \\
\text { cara } \\
\text { memenuhi } \\
\text { standar } \\
\text { mutu }\end{array}$ & 0.656 & 0.482 & Valid \\
\hline B1 & $\begin{array}{l}\text { Pelaksa- } \\
\text { naan } \\
\text { Rencana } \\
\text { Mutu }\end{array}$ & 0.568 & 0.482 & Valid \\
\hline B2 & $\begin{array}{l}\text { Kegiatan } \\
\text { sistemik } \\
\text { dalam } \\
\text { melaksana- } \\
\text { kan mutu } \\
\text { untuk } \\
\text { memenuhi } \\
\text { persyaratan } \\
\text { yang telah } \\
\text { ditetapkan }\end{array}$ & 0.845 & 0.482 & Valid \\
\hline C1 & $\begin{array}{l}\text { Memantau } \\
\text { hasil-hasil } \\
\text { spesifik } \\
\text { Proyek }\end{array}$ & 0.800 & 0.482 & Valid \\
\hline C2 & $\begin{array}{l}\text { Menentu- } \\
\text { kan } \\
\text { penyimpan } \\
\text { gan } \\
\text { terhadap } \\
\text { standar }\end{array}$ & 0.580 & 0.482 & Valid \\
\hline & & & \\
\hline
\end{tabular}




\begin{tabular}{|l|l|l|l|l|}
\hline C3 & $\begin{array}{l}\text { Mengidenti } \\
\text { fikasi } \\
\text { tindakan } \\
\text { untuk }\end{array}$ & & & \\
menghilang & 0.656 & 0.482 & Valid \\
kan & & & \\
penyebab & & & \\
kinerja & & & \\
yang tidak & & & \\
memuaskan & & & \\
\hline
\end{tabular}

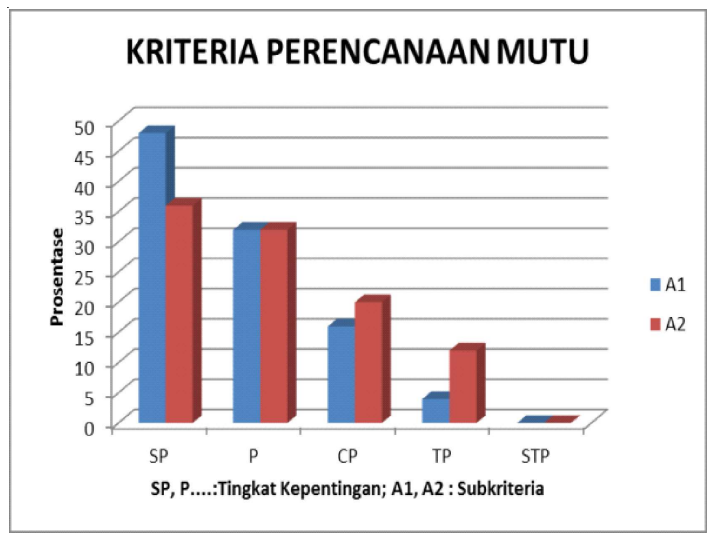

Gambar 2. Frekuensi Kriteria Perencanaan Mutu

Dari gambar tersebut dapat dilihat bahwa:

- Pada subkriteria A1 responden yang menjawab sangat penting sebanyak $48 \%$, penting $32 \%$, cukup penting $16 \%$ dan tidak penting $4 \%$.

- Pada subkriteria A2 responden yang menjawab sangat penting sebanyak $36 \%$, penting $32 \%$, cukup penting $20 \%$ dan tidak penting $12 \%$.

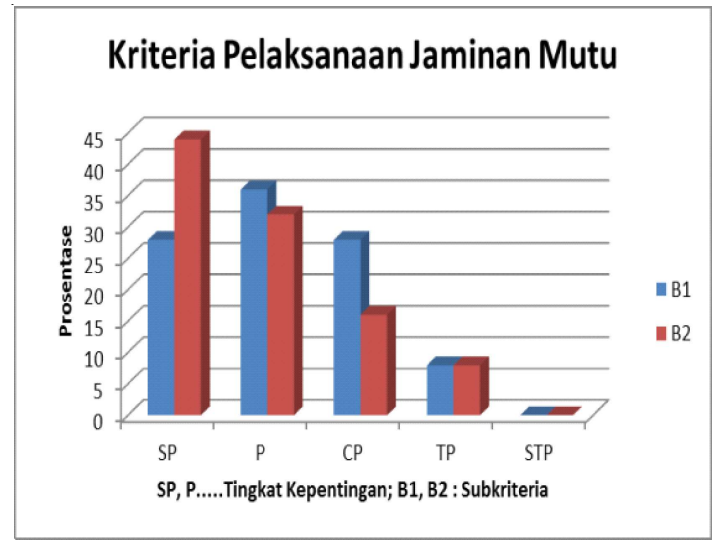

Gambar 3. Frekuensi kriteria Pelaksanaan Jaminan Mutu

Dari gambar tersebut dapat dilihat bahwa:

- Pada subkriteria B1 responden yang menjawab sangat penting sebanyak $28 \%$, penting $36 \%$, cukup penting $28 \%$ dan tidak penting $8 \%$.

- Pada subkriteria B2 responden yang menjawab sangat penting $44 \%$, penting $32 \%$ dan cukup penting $16 \%$, tidak penting $8 \%$.

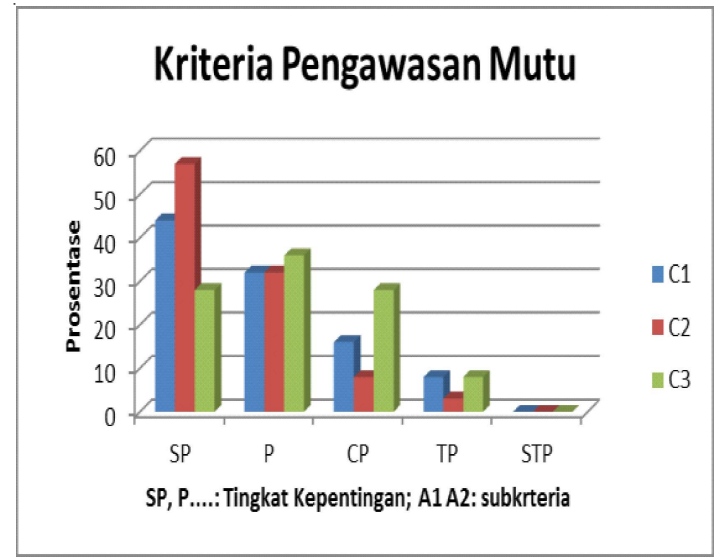

Gambar 4. Frekuensi kriteria Pengawasan Mutu

Dari gambar tersebut dapat dilihat bahwa:

- Pada subkriteria C1 responden yang menjawab sangat penting sebanyak $44 \%$, penting $32 \%$, cukup penting $16 \%$ dan tidak penting $8 \%$. 
- Pada subkriteria C2 responden yang menjawab sangat penting $57 \%$, penting $32 \%$, cukup penting $8 \%$ dan tidak penting $3 \%$.

- Pada subkriteria C3 responden yang menjawab sangat penting sebanyak $28 \%$, penting $36 \%$, cukup penting $28 \%$ dan tidak penting $8 \%$.

Dari hasil uji di atas maka dapat disimpulkan bahwa semua kriteria dan sub kriteria adalah memenuhi syarat valid dan reliabel.
Setelah kriteria ditetapkan, maka dapat dilakukan analisa penerapan sistem manajemen mutu berdasarkan pada kriteria-kriteria di atas. Analisa ini menggunakan teknik Zero One, yaitu dengan melakukan pembobotan dan perangkingan pada alternatif-alternatif yang tersedia.

Tabel 3. Pembobotan kriteria untuk menentukan ranking

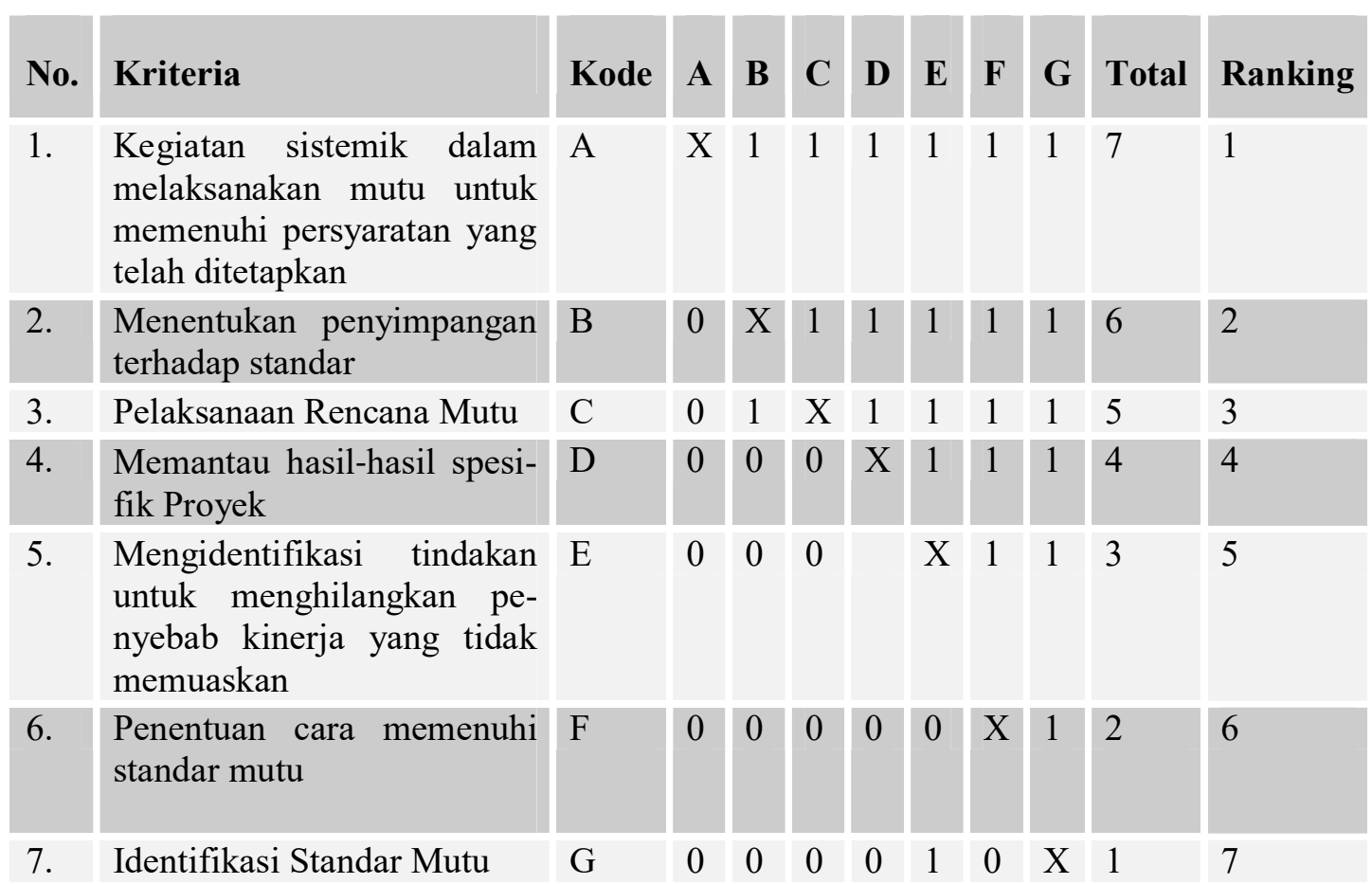

Tabel 4. Pembobotan dengan Metode Kuantitatif Subyektif

\begin{tabular}{|c|c|c|c|c|}
\hline No. & Kriteria - kriteria & Kode & Ranking & Bobot \\
\hline 1. & $\begin{array}{l}\text { Kegiatan sistemik dalam melaksanakan } \\
\text { mutu untuk memenuhi persyaratan yang } \\
\text { telah ditetapkan }\end{array}$ & A & 1 & 1,00 \\
\hline 2. & $\begin{array}{l}\text { Menentukan penyimpangan terhadap } \\
\text { standar }\end{array}$ & B & 2 & 0,93 \\
\hline 3. & Pelaksanaan Rencana Mutu & $\mathrm{C}$ & 3 & 0,86 \\
\hline 4. & Memantau hasil-hasil spesifik Proyek & $\mathrm{D}$ & 4 & 0,79 \\
\hline
\end{tabular}


$\square \quad 120 \mid$ JUTEKS Jurnal Teknik Sipil Volume 1 Nomor 2 Oktober 2016

5. Mengidentifikasi tindakan untuk menghilangkan penyebab kinerja yang E 5 0,71 tidak memuaskan

\begin{tabular}{|l|l|l|l|l|}
\hline 6. & Penentuan cara memenuhi standar mutu & F & 6 & 0,64 \\
\hline 7. & Identifikasi Standar Mutu & G & 7 & 0,57
\end{tabular}

Dari Tabel 4, jumlah kriteria dalam penerapan SMM adalah 7 kriteria. Pembobotan setiap kriteria menggunakan rumus sebagai berikut :

Bobot $=\frac{N-t+1}{N}$ dimana :

$\mathrm{N}=$ jumlah kriteria

$\mathrm{t}=$ urutan ranking

Setelah dilakukan pembobotan, langkah terakhir adalah pemilihan lokasi terbaik dengan memilih nilai skor yang tertinggi, seperti yang diperlihatkan pada Tabel 5 .

Tabel 5. Penentuan Alternatif Penerapan SMM

\begin{tabular}{|c|c|c|c|c|c|c|c|c|c|c|c|}
\hline \multirow{3}{*}{ No. } & \multirow{3}{*}{$\begin{array}{l}\text { Alternatif } \\
\text { Penerapan } \\
\text { SMM }\end{array}$} & \multicolumn{8}{|c|}{ Kriteria } & \multirow{3}{*}{ Total } & \multirow{3}{*}{ Rankin } \\
\hline & & \multirow[b]{2}{*}{ Bobot } & $\mathbf{A}$ & B & C & D & $\mathbf{E}$ & $\mathbf{F}$ & G & & \\
\hline & & & 1,00 & 0,93 & 0,86 & 0,79 & 0,71 & 0,64 & 0,57 & & \\
\hline \multirow[t]{2}{*}{1.} & $\begin{array}{l}\text { Penerapan } \\
\text { SMM } \\
\text { dilakukan } \\
\text { secara } \\
\text { Sistematis }\end{array}$ & & 2 & 1 & 2 & 3 & 2 & 3 & 3 & & 2 \\
\hline & Jumlah & & 2,00 & 0,93 & 1,72 & 2,37 & 1,42 & 1,92 & 1,71 & 12,07 & \\
\hline \multirow[t]{2}{*}{2.} & $\begin{array}{l}\text { Penerapan } \\
\text { SMM belum } \\
\text { berjalan } \\
\text { sebagaimana } \\
\text { mestinya }\end{array}$ & & 5 & 4 & 2 & 1 & 1 & 2 & 1 & & 1 \\
\hline & Jumlah & & 5 & 3,72 & 1,72 & 0,79 & 0,71 & 1,28 & 0,57 & 13,79 & \\
\hline
\end{tabular}

Keterangan:

Jumlah $=$ bobot $\mathrm{x}$ nilai

Total = jumlah $\mathrm{A}+\mathrm{B}+\mathrm{C}+\mathrm{D}+\mathrm{E}+\mathrm{F}+\mathrm{G}$

Dengan demikian, berdasarkan pada hasil analisis di atas maka dapat diperoleh suatu gambaran bahwa Penerapan Sisitem Manajemen Mutu pada Industri Jasa Konstruksi belum berjalan dengan baik, walupun pada dasarnya Responden memiliki pemahaman yang cukup baik tentang Kriteria-kriteria yang dipakai dalam membangun Sistem Manajemen Mutu. 


\section{KESIMPULAN}

Dari berbagai analisa terdahulu dapat disimpulkan dua hal berkaitan dengan tujuan dari penelitian ini yaitu:

1.Kriteria-kriteria yang dipakai dalam menilai Penerapan Sistem Manajemen Mutu adalah kriteria yang telah diuji validitas, reliabilitas dan uji frekwensi serta beda rata-rata. Kriteriakriteria tersebut dijadikan sebagai indikator utama untuk menilai apakah penerapan SMM telah berjalan baik ataukah belum berjalan baik

2.Hasil survey menunjukkan bahwa penerapan SMM belum berjalan baik pada berbagai kontraktor.

Hasil ini menegaskan fenomena atau fakta yang terjadi bahwa sering terjadi kegagalan pada pelaksanaan proyek konstruksi. Salah satunya sebagai akibat tidak diterapkannya suatu sistem manajemen mutu yang baik.

\section{DAFTAR PUSTAKA}

Colona, S. (2008), Entrepreneurial Skills Development Programme, International Training Centre of ILO, Turin (Italia).

Febriandi Raymond (2007), Sistem Manajemen Mutu ISO 9001:2000 pada Industri Jasa Konstruksi, FT Univ. Soegyapranoto

Latief, Yusuf (2009), Penerapan Metode Six Sigma dalam penjagaan kualitas pada proyek konstruksi, Jurnal Makara Teknologi, Vol.13 No.2-November 2009.

Moeldjanto, H.,(2004), Sistem Manajemen Mutu Bidang Pengairan,....

Bria, M., (2009), Perencanaan Sistem Manajemen Mutu, Diktat Kuliah, JTS PNK.

Ravichandran, et.al (2000), Quality Management In Systems Development: An Organizational System Perspective, MIS Quarterly Vol. 24 No.3 pp. 381-415.

Tangkilisan, H.N.S. Drs. (2004), Mana-jemen Modern untuk Sektor Publik, Balai-rung \& $\mathrm{CO}$, Yogyakarta. 